\title{
Symptomatic and asymptomatic bacteriuria in a pediatric cohort of kidney transplants from a hospital in Paraguay
}

\section{Bacteriuria sintomática y asintomática en una cohorte pediátrica de trasplantados renales de un hospital en Paraguay}

Avelina Victoria Troche ${ }^{1,2^{*}}$, Marlene Martínez-Pico ${ }^{1,2}$, Nidia Gómez $^{1,2}$, Fernando Galeano², Víctor Araya ${ }^{3}$, Marcos Roberto Tovani-Palone ${ }^{4}$, Soraya Araya ${ }^{2}$

ABSTRACT
Introduction: Bacteriuria is common in kidney transplant recipients (KTR) and it may affect graft survival.

Objective: To describe the incidence, clinical manifestations and microbial susceptibility of the symptomatic (SB) and asymptomatic (AB) bacteriuria in KTR, and to define the initial empirical treatment.

Methods: Retrospective cohort study of all KTR $<18$ years with bacteriuria that were transplanted between January 2006 and December 2016 . Clinical, demographic, laboratory characteristics and follow-up time were investigated. Bacteriuria was classified as either SB or AB. Statistical analysis was performed using Excel 2010 program.

Results: 20 kidney transplants were performed. The female/male ratio was approximately $2: 1$ and $45 \%$ of the patients had bacteriuria. Of the 55 bacteriuria episodes, 20 were symptomatic and 35 asymptomatic. The mean age of the patients was $10.7 \pm 4.7$ years. The more frequent primary renal diseases were neurogenic bladder (44.4\%), renal dysplasia (22.2\%), nephronophthisis, vesicoureteral reflux and obstructive uropathy (11.1\% each). The median number of episodes/patient was 3.9. The mean time to post-transplant presentation was $<6$ months in $25 \%$ of the cases, $6-12$ months in $20 \%$ and $>12$ months in $54.5 \%$. The median time between the transplantation and the first AB episode was 3 months, and between the first SB episode was 7 months. The symptoms found in patients with SB included fever ( $80 \%)$, hematuria (15\%) and septic shock (5\%). No patient died due to urinary tract infections (UTI), but $33.3 \%$ of the patients with bacteriuria required admission to intensive care units. The most frequent bacteria isolated was Escherichia coli (E.coli) (54.5\%). Extended-spectrum beta-lactamase (ESBL) producing bacteria was found in 20\% of the isolates. When comparing SB and $A B$, E.coli was associated with SB ( $p=0.047$ OR:1-9.9). All SB cases were verified in patients with neurogenic bladder $(p=0.013)$.

Conclusion: The recognition of high incidence of ESBL producing bacteria- related to UTI in (children) KTR may be very important for decision on the use of antibiotics during post- transplantation period. In this case, the use of carbapenem and ciprofloxacin should be recommended as initial empiric treatment.

Keywords: urinary tract infection, renal transplantation, child

\footnotetext{
1 Pediatric Nephrology Unit. Hospital Central del Instituto de Previsión Social, Paraguay.

2 Universidad Católica Nuestra Señora de la Asunción, Campus Asunción, Paraguay.

3 Hillmont GI, United States.

4 Ribeirão Preto Medical School, University of São Paulo, Brazil.

Correspondence: Avelina Victoria Troche

Unidad de Nefrología Pediátrica, Hospital Central del Instituto de Previsión Social, Paraguay

E-mail: avtrocheh@yahoo.com.ar
}

Received: 14 Sep 2018, Accepted: 14 Apr 2019

(C) 2019 by the authors; licensee Modestum Ltd., UK. This article is an open access article distributed under the terms and conditions of the Creative Commons Attribution License (http://creativecommons.org/licenses/by/4.0/). 


\section{RESUMEN}

Introducción: La bacteriuria es común en los receptores de trasplante renal (RTR) y puede afectar la sobrevida del injerto.

Objetivo: Describir la incidencia, manifestaciones clínicas y sensibilidad microbiana de las bacteriurias sintomáticas (BS) y asintomáticas (BA) en los RTR, para definir el tratamiento empírico inicial.

Métodos: Estudio de cohorte retrospectivo, de todos los RTR menores de 18 años de edad con bacteriuria que fueron trasplantados desde enero de 2006 a diciembre de 2016. Se estudiaron las características clínicas, demográficas, laboratoriales y el seguimiento de los pacientes. Las bacteriurias se categorizaron en BS y BA. El análisis estadístico se realizó con el programa Excel 2010.

Resultados: Se realizaron 20 trasplantes renales. La relación mujer/hombre fue de aproximadamente 2: 1 y $45 \%$ de los RTR desarrollaron bacteriuria. De 55 episodios de bacteriuria, 20 fueron sintomáticos y 35 asintomáticos. La edad media de los pacientes fue de $10.7 \pm 4.7$ años. Las enfermedades renales primarias más frecuentes fueron vejiga neurogénica (44.4\%), displasia renal (22.2\%), nefronoptisis, reflujo vésicoureteral y uropatía obstructiva ( $11 \%$, cada uno). La mediana de episodios por paciente fue 3.9. El período de presentación post-trasplante fue $<6$ meses en $25 \%$ de los casos, $6-12$ meses en $20 \%$ y $>12$ meses en 54.5\%. La mediana de tiempo entre el trasplante y el primer episodio de BA fue de 3 meses, y 7 meses para el primer episodio de BS. Los síntomas encontrados en los pacientes con BS fueron fiebre (80\%), hematuria (15\%) y choque séptico (5\%). Ningún paciente falleció de infecciones del tracto urinario (ITU), pero 33.3\% de los pacientes con bacteriuria requirió cuidados intensivos. El germen más frecuente fue Escherichia coli (E. coli) (54.5\%). Se encontraron bacterias productoras de betalactamasas de espectro extendido (BLEE) en $20 \%$ de los aislamientos. Al comparar BS vs BA, E. coli se asoció con BS ( $p=0.047$ OR:1-9.9), y todos los episodios de BS se presentaron en pacientes con vejiga neurogénica ( $p=$ 0.013).

Conclusión: El reconocimiento de una alta incidencia de bacterias productoras de BLEE relacionadas con la ITU en niños (RTR) puede ser muy importante para tomar una decisión sobre el uso de antibióticos durante el periodo post-trasplante. En este caso, el uso de carbapenem y ciprofloxacina puede recomendarse como tratamiento empírico inicial.

Palabras clave: infección del tracto urinario, trasplante renal, niño

\section{INTRODUCTION}

Transplantation is the renal replacement therapy of choice for patients with pediatric chronic renal failure (1). Overall, the survival of patients submitted to renal graft has improved markedly in the pediatric population. However, renal graft survival depends on immunological and non-immunological factors such as hypertension, and urinary tract infections (UTI). UTI may cause scarring of the transplanted kidney and interstitial injury $(1,2)$.

Post-transplant UTI continues to be one of the main causes of morbidity and mortality, since $60 \%$ of bacteremia is associated with such disorder (3). Their clinical presentation is variable and ranges from asymptomatic forms to symptomatic febrile UTI (with or without acute pyelonephritis), which can compromise patient care and graft prognosis $(3,4)$. Acute pyelonephritis (when present) is characterized by the occurrence of fever, chills, pain at graft area and hematuria, and it should be differentiated from acute rejection (4).

According to the literature, accepted risk factors for febrile UTI development include abnormal anatomy, bladder dysfunction, immunosuppression, presence of a foreign body (such as urological catheters and stents), and patient demographic factors (5). Urological abnormalities, in turn, include hydronephrosis, vesicoureteral reflux, and neurogenic bladder, which often in combination, predispose to UTI (6).

Some scientific reports have showed that the more frequent bacteria involved in UTI during the post-transplant period are gram-negative bacilli, especially Escherichia coli (E. coli), Klebsiella spp, Pseudomonas aeruginosa and Enterococcus spp. This implies, in particular, that there is a high prevalence of multi-resistant germs in this context, which could increase morbidity and mortality in transplant patients as well as cases of graft loss (7-10).

Recently, American and European researchers reported that there is difference in the UTI frequency (41\% and $33 \%$, respectively) among people around the world, due to individual differences (11).

Data about UTI in kidney transplant recipients (KTR) in Paraguay are scarce. Knowledge of microbial susceptibility is very important, given that this may contribute to decision about the initial empirical treatment to specific pathologies, in order to avoid the proliferation of multi-resistant organisms and complications (12).

The aim of the present study was to find out the incidence, clinical manifestations, causal agents and antibiotic sensitivity related to symptomatic (SB) and asymptomatic bacteriuria (AB) in KTR in order to decide the best initial empirical treatment for this group of patients.

\section{METHODS}

This was an observational, descriptive, retrospective cohort study that included all KTR under 18 years of age $(n=20)$ with bacteriuria that were transplanted between January 2006 to December 2016 in the Pediatric Nephrology Unit of the Hospital Central del Instituto de Prevision Social in Paraguay. 
According to the kidney transplant protocol of our Institution, the urine culture of each patient was requested at each post-transplant visit. Clean-catch midstream voided urine specimens were collected, except in patients with neurogenic bladder who needed bladder catheterization. The samples were stored in sterile bottles and processed immediately.

Urinalysis was performed through test strip (Urocolor $10{ }^{\circledR}$ Standard Diagnostics INC, Korea). Microscopic observation of the urinary sediment was used to diagnosis of leukocyturia or evaluation for the presence of bacteria using gram stain.

We considered for diagnosis of urinary infection the following parameters: presence of nitrites and leukocyte esterase on the dipstick, as well as the microscopic observation of bacteria and leukocytes in the urinary sediment.

Based on urine culture, the account of colony forming units and resistance of bacteria were evaluated. The used culture mediums were selective (Eosin methylene blue (Britania, Argentina)) and not selective (Agar blood (Biomerieux, France)).

The microbial susceptibility and presence of extended-spectrum-beta-lactamase (ESBL) and carbapenemase were evaluated using the automated system VITEK ${ }^{\circledR} 2 C$ (Biomerieux, France).

Minimum inhibitory concentrations (for the in vitro susceptibility study) were determined according to the recommendations of the Clinical and Laboratory Standards Institute. Presence of ESBL and carbapenemase was identified by the Advanced Expert System ${ }^{\mathrm{TM}}$ of the automated device.

All patients received triple immunosuppressive therapy with a calcineurin inhibitor, corticosteroid and mycophenolate mofetil. Seven of the nine patients with episodes of bacteriuria received induction therapy using interleukin 2 receptor antagonists (basiliximab, $10 \mathrm{mg}$ (if patient $<35 \mathrm{~kg}$ ) or $20 \mathrm{mg}$ (if patient $>35 \mathrm{~kg}$ ), through a bolus injection at the beginning of the surgery and on day 4 post-transplant). Corticosteroids were started intraoperatively (methylprednisolone at a dose of $15 \mathrm{mg} / \mathrm{kg}$ and rotating to prednisone $2 \mathrm{mg} / \mathrm{kg} /$ day, with a maximum dose of 60 $\mathrm{mg} /$ day (from day 1 postoperative), which was gradually tapered). Cyclosporin A levels were maintained between 150 to $200 \mathrm{ng} / \mathrm{ml}$ in the first 3 months after transplant and 100 to $150 \mathrm{ng} / \mathrm{ml}$ after the third month of the procedure. Tacrolimus levels were maintained between 10 to $15 \mathrm{ng} / \mathrm{ml}$ during the first month after transplant and between 5 to $10 \mathrm{ng} / \mathrm{ml}$ after the first month of the procedure. All patients received prophylaxis for Pneumocystis jirovecii with trimethoprim/sulfamethoxazole for six months.

Clinical, demographic, laboratory characteristics as well as follow up time were evaluated and categorized into two groups ( $S B$ and $A B)$.

Statistical analysis was performed using Excel 2010 program. Qualitative data were presented as numbers and percentages, and quantitative data as mean, median and standard deviation. The categorical variables were compared with the chi square test and $\mathrm{P}$ values smaller than 0.05 were considered statistically significant.

Study definitions:

- Asymptomatic bacteriuria was defined as an isolation of $\geq 10{ }^{5} \mathrm{cfu} / \mathrm{mL}$ in a single, clean-catch, voided urine specimen obtained from a person without symptoms or signs referable to urinary infection.

- Symptomatic bacteriuria was defined as an isolation of a single bacteria and a count of $\geq 10^{5} \mathrm{cfu} / \mathrm{mL}$ in a single, clean-catch, voided urine specimen, or of $\geq 10^{3} \mathrm{cfu} / \mathrm{mL}$ in a sample obtained by bladder catheterization from a patient with clinical manifestations referable to urinary infection such as dysuria, frequency, urgency, fever and changes in the urine color.

\section{RESULTS}

In the study period, 20 children and adolescents were transplanted in our Hospital. 45\% of them (9/20) had bacteriuria. The characteristics of the patients are described in Table 1. 
Table 1: Characteristics of the studied patients

\begin{tabular}{lc}
\hline Number of patients & 20 \\
\hline Recipient age & $10,7 \pm 4,7$ \\
\hline Number of patients with bacteriuria & $9 / 20(45 \%)$ \\
\hline Number of episodes of bacteriuria & 55 \\
\hline Gender & 19 \\
\hline Male & 36 \\
\hline Female & $\cong 2: 1$ \\
\hline Memale: Male & $3,9(1$ a 17$)$ \\
\hline Primary renal disease & \\
\hline Neurogenic bladder & $4 / 9(44.4 \%)$ \\
\hline Renal dysplasia & $2 / 9(22.2 \%)$ \\
\hline Nephronophthisis, & $1 / 9(11.1 \%)$ \\
\hline Vesicoureteral reflux & $1 / 9(11.1 \%)$ \\
\hline Complex uropathy & $1 / 9(11.1 \%)$ \\
\hline
\end{tabular}

The primary renal diseases found were neurogenic bladder in $44.4 \%$ of the patients (4/9), renal dysplasia in $22.2 \%$ (2/9), nephronophthisis, vesicoureteral reflux and uropathy in $11.1 \%$ each (1/9).

Of the 55 bacteriuria events, 20 were symptomatic (36\%) and $35(64 \%)$ asymptomatic. The average time between the transplantation and the first $A B$ episode was 3 months ( 0.5 to 12 months), while for the first SB episode was 7 months (1 to 24 months).

The most frequent bacteria isolated were $E$. coli in $54.5 \%$ of the isolates (30/55), followed by Klebsiella pneumonia in $12.7 \%(7 / 55)$, Enterococcus faecalis in 9.1\% (5/55) and Enterobacter cloacae in 7.3\% (4/55). Extended-spectrum betalactamase-producing bacteria were found in $20 \%$ of the isolates (11/55).

When comparing SB with $A B$, we found that E.coli was associated with SB ( $p=0.047$ OR: 1-9.9). All SB episodes occurred in patients with neurogenic bladder $(p=0.013) .33 .3 \%$ of the patients with bacteriuria $(3 / 9)$ presented a decrease in glomerular filtration rate after an average time of 6 months post-transplant.

No mortality was recorded due to urinary infection in the present study, however in $33.3 \%$ of the patients with bacteriuria (3/9) intensive therapy care was required.

\section{DISCUSSION}

Infections are the main cause of post-transplant hospitalizations, with UTI being the most common. Such disorders can potentially cause kidney scarring and interstitial fibrosis, and even graft dysfunction (2).

According to reports from different authors, the frequency of urinary infection in post-renal transplant patients varies from $7.3 \%$ to $75 \%$, which could be explained by the lack of uniformity in the UTI definitions and differences in the followup period $(4,13)$. In our group of patients, the UTI frequency was $45 \%$, with similar results as reported by Wu et al. (2016) (11): Our finding concerning the most common bacteria related to bacteriuria in KTR (E. coli) is consistent with the results of other studies $(4,13)$. Furthermore, we found a higher UTI prevalence in females, which corroborates the results of John et al. (2006) (14). It should be also noted that, in the present study, congenital diseases were the most frequent causes of renal failure and transplant requirement.

Another relevant point is that the time of presentation of post-transplant bacteriuria in most of our patients was after 6 months of transplantation. In addition, the average time between transplantation and the first episode of $A B$ was 3 months (with a range of 15 days to 12 months), while for the first episode of SB was 7 months (with a range of 1 to 24 months). This finding does not coincide with previous studies, given that the first semester post-transplantation is considered a decisive time frame for developing UTI due to the use of urinary tract instrumentation and intensive immunosuppression (13). Late infections (occurring more than 6 months after transplant) are usually secondary (1).

Previous studies determined that anatomic or functional abnormalities of the lower urinary tract carry a higher risk of developing UTI in the post-transplant period. According to these authors, such infections should be resolved before transplantation. The increased risk of UTI in patients with neurogenic bladder, for instance, can be minimized with good patient selection, correct bladder emptying and maintaining low intravesical pressures (15). Our patients were evaluated in the pre-transplant period through radiological and urodynamic analysis and underwent cystoplasty (if required). We hypothesized that SB episodes in this group of patients could be due to lack of adherence to clean intermittent catheterization. Moreover, the patients did not present SB episodes in the first 6 months post- transplantation because 
they received prophylaxis for Pneumocystis jiroveci with trimethoprim-sulfamethoxazole, which would also treat the most common microorganisms found in our study.

Data from the literature suggest that patients undergoing kidney transplantation have a higher risk of developing UTI from resistant bacteria (16). The frequency of isolation of ESBL- producing bacteria in our Institution was $20 \%$, which is numerically lower than the frequency reported by other researchers (4). After the present findings we decided to use carbapenem or ciprofloxacin (which should cover ESBL- producing bacteria) (17) as initial empirical antibiotic regimen for all patients with symptomatic bacteriuria episodes. This regimen was adjusted based on the culture report and microbial susceptibility test findings.

The UTI recurrence rate observed in our patients was $72 \%$, which is similar to the published literature (18). Dupont et al. (2007) (19) reported that more than half of post-transplant patients with recurrent UTI develop renal scarring. However, we did not observe this finding in our patients. We found, moreover, that $33.3 \%$ of the patients with bacteriuria required admission to intensive care units, and all patients survived. This is similar to the findings of Giraldo-Ramírez et al. (2016) (13).

Although our study is limited by the fact that it is retrospective and has a small sample size, it may be considered relevant for the population of KTR, since it included all children who had received a kidney transplant from January 2006 to December 2016 in a reference hospital from Paraguay.

In conclusion, the UTI occurrence post-kidney transplant is a condition that influences both the health of patients and graft survival. In this regard, the recognition of high incidence of ESBL producing bacteria- related to UTI in (children) KTR may be very important for decision on the use of antibiotics during post- transplantation period. In this case, the use of carbapenem and ciprofloxacin may be recommended as initial empiric treatment. Our findings have, therefore, led to significant changes in patient management from our Kidney Transplant Unit. Furthermore, it seems that in the pediatric population there are important differences in the causes and severity of UTI complications when compared with adult series, given that most of these complications in children are due to congenital diseases. In order to answer this question we plan to continue our study, with the inclusion of a larger sample size for comparison with the adult renal transplant population.

\section{Conflict of interest}

The authors declare that there is no conflict of interest.

\section{REFERENCES}

1. Karuthu S, Blumberg EA. Common infections in kidney transplant recipients. Clin J Am Soc Nephrol. 2012;7(12):2058-70. https://doi.org/10.2215/CJN.04410512 PMid:22977217

2. Mudalige NL, Kessaris N, Stojanovic J, Marks SD. Improved outcomes for paediatric renal transplant recipients. Paediatr Child Health (Oxford). 2018;28(7): 337-43. https://doi.org/10.1016/j.paed.2018.04.007

3. Ko KS, Cho DO, Ahn JH, et al. Infections after renal transplantation. Transplant Proc. 1994; 26(4):2072-4.

4. Chacón-Mora N, Díaz JP, Matía EC. Urinary tract infection in kidney transplant recipients. Enferm Infecc Microbiol Clin. 2017;35(4):205-70. https://doi.org/10.1016/j.eimc.2016.03.003 PMid:27112976

5. Sharifian M, Rees L, Trompeter RS. High incidence of bacteriuria following renal transplantation in children. Nephrol Dial Transplant. 1998;13(2):432-5. https://doi.org/10.1093/oxfordjournals.ndt.a027842 PMid:9509458

6. Cairns HS, Spencer S, Hilson AJ, Rudge CJ, Neild GH. 99mTc-DMSA imaging with tomography in renal transplant recipients with abnormal lower urinary tracts. Nephrol Dial Transplant. 1994;9(8):1157-61. https://doi.org/10.1093/ndt/9.8.1157 PMid:7800217

7. Souza RM, Olsburgh J. Urinary tract infection in the renal transplant patient. Nat Clin Pract Nephrol. 2008;4(5):252-64. https://doi.org/10.1038/ncpneph0781 PMid:18334970

8. Vidal $\mathrm{E}$, Torre-Cisneros J, Blanes $\mathrm{M}$, et al. Bacterial urinary tract infection after solid organ transplantation in the RESITRA cohort. Transpl Infect Dis. 2012;14(6):595-603. https://doi.org/10.1111/j.1399-3062.2012.00744.x PMid:22650416

9. El Amari EB, Hadaya $K$, Bühler $L$, et al. Outcome of treated and untreated asymptomatic bacteriuria in renal transplant recipients. Nephrol Dial Transplant. 2011;26(12):4109-14. https://doi.org/10.1093/ndt/gfr198 PMid:21592976 
10. Aguado JM, Silva JT, Fernández-Ruiz $M$, et al. Management of multidrug resistant Gram-negative bacilli infections in solid organ transplant recipients: SET/GESITRA-SEIMC/REIPI recommendations. Transplant Rev (Orlando). 2018;32(1):36-57. https://doi.org/10.1016/j.trre.2017.07.001 PMid:28811074

11. Wu X, Dong Y, Liu Y, et al. The prevalence and predictive factors of urinary tract infection in patients undergoing renal transplantation: a meta-analysis. Am J Infect Control. 2016;44(11):1261-8. https://doi.org/10.1016/j.ajic.2016.04.222 PMid:27311513

12. Khosravi $A D$, Abasi Montazeri $E$, Ghorbani $A$, Parhizgari $N$. Bacterial urinary tract infection in renal transplant recipients and their antibiotic resistance pattern: a four-year study. Iran J Microbiol. 2014;6(2):74-8.

13. Giraldo-Ramírez S, Díaz-Portilla OE, Miranda-Arboleda AF, Henao-Sierra J, Echeverri-Toro LM, Jaimes F. Urinary tract infection leading to hospital admission during the first year after kidney transplantation: a retrospective cohort study. Transplantation Reports. 2016;1(3-4):18-22. https://doi.org/10.1016/j.tpr.2016.09.001

14. John U, Everding AS, Kuwertz-Broking E, et al. High prevalence of febrile urinary tract infections after paediatric renal transplantation. Nephrol Dial Transplant. 2006;21(11):3269-74. https://doi.org/10.1093/ndt/gfl464 PMid:16963479

15. Akia FT, Aydina AM, Dogana HS, et al. Does lower urinary tract status affect renal transplantation outcomes in children? Transplant Proc. 2015;47(4):1114-6. https://doi.org/10.1016/j.transproceed.2014.10.069 PMid:26036532

16. Korayem GB, Zangeneh TT, Matthias KR. Recurrence of urinary tract infections and development of urinaryspecific antibiogram for kidney transplant recipients. J Glob Antimicrob Resist. 2018;12:119-23. https://doi.org/10.1016/j.jgar.2017.08.009 PMid:28859935

17. Dhillon RH, Clark J. ESBLs: a clear and present danger?. Crit Care Res Pract. 2012;2012:625170. https://doi.org/10.1155/2012/625170 PMid:21766013 PMCid:PMC3135063

18. Silva $A$, Rodig $N$, Passerotti $C P$, et al. Risk factors for urinary tract infection after renal transplantation and its impact on graft function in children and young adults. J Urol. 2010;184(4):1462-7. https://doi.org/10.1016/j.juro.2010.06.028 PMid:20727542

19. Dupont PJ, Psimenou E, Lord R, Buscombe JR, Hilson AJ, Sweny P. Late recurrent urinary tract infections may produce renal allograft scarring even in the absence of symptoms or vesicoureteric reflux. Transplantation. 2007;84(3):351-5. https://doi.org/10.1097/01.tp.0000275377.09660.fa PMid:17700160

$\diamond \diamond \diamond \diamond \diamond \diamond \diamond$

http://www.ejgm.co.uk 